\title{
LEI E REGULAMENTO
}

\author{
VÍTOR NUNES LEAL \\ Prof.. de Política en a Faculdade \\ Nacional de Filosofia
}

SUMÂRIO $\quad I-A$ competência legislativa na Constituição de 1937. II - Regime de legalidade. III - Distinção entre lei e regulamento: Opiniōes de HAURIOU e DUGUIT. Dístinção formal pela indicação da competência - Sobrevivência da hierarquia entre lei e regulamento - Matéria dos regulamentos - Execução provisória de tratados - O Conselho da Economia Nacional. IV - Classificação e aplicaçấo dos regulamentos. $V$ Conclusão.

\section{A COMPETÊNCIA LEGISLATIVA NA CONSTITUIÇÃO DE 1937}

1. Apesar do sentido genérico do título, são muito modestos os limites do presente comentário. Não temos outro propósito senão o de estabelecer um confronto entre a lei e o regulamento, à luz das disposições constitucionais vigentes.

O assunto pareceu-nos de atualidade, por um lado, devido à competência legislativa originária que a Constituição outorga, em certa matéria, ao Presidente da Repŕblica, e, de outro, em face do regime atual de cumulação de tôda a função legislativa e também da função constituinte nas mãos do Chefe de Estado.

2. A Constituição de 10 de novembro, comparada com as nossas Constituições anteriores, operou, como é sabido, profunda alteração na distribuição da competência legislativa.

As Constituições de 1824 e 1891 , embora estruturando regimes tão điversos, haviam atribuído a função legislativa precìpuamente ao Parlamento (Assembléia Geral, no Império, e Congresso Nacional, na República). Ao Chefe do Estado competia colaborar na tarefa legislativa através da sanção e do veto, mas o órgão essencialmente legislativo era o parlamento. A prática das delegações legislativas, tanto no regime imperial como no republicano, temperava êsse mo- 
nopólio das câmaras, embora combatida por muitas vozes autorizađas como ofensiva do princípio da separação de poderes 1 .

A Constituição de 1934 foi ainda mais longe que as anteriores, porque expressamente proibiu as delegações legislativas: " $E$ ' vedado aos poderes constitucionais delegar as suas atribuições" (art. 3. , $\left.\S 1 .^{\circ}\right)$. Essa disposição constitucional deu oportunidade a uma polêmica famosa entre o Sr. Oliveía Viaña e o então deputado Val Demar Ferreira, quando se discutia na Câmara o Projeto Agamemnon Magalhães de organização da Justiça do Trabalho. O Projeto governamental conferia à Justiça do Trabalho as chamadas funções normativas que o Sr. VALDEMAR FERREIRA considerava incompatíveis com a proibição constitucional da delegação de poder. Esforçou-se o Sr. Oliveira Viana por demonstrar o contrário, com grande erudição, mas contra a sua tese erguia-se o texto constitucional expresso e inequívoco 2. A polêmica não chegou ao têrmo, porque sobreveio a Constituição de 1937 , que passou a permitir expressamente as delegações legislativas (art. 12).

No tocante à competência legislativa, a Constituição atual alterou completamente o sistema anterior, coerente com o seu espirito, que foi o de dar ao Chefe do Estado uma preeminência incontrastável no regime político 3 . Modificou consideràvelmente o processo de elaboração de leis pelo parlamento (arts. 64-66) e, além disso, distribuiu a competência legislativa entre o Parlamento e o Presidente da República. E' êste o ponto que mais de. perto nos interessa.

Pelo art. 14, foi o Chefe do Estado autorizado a expedir livremente decretos-leis sôbre a organização do govêrno e da administração federal, o comando supremo e a organização das fôrças armadas, contanto que observadas as disposições constitucionais e respeitados os limites das respectivas dotações orçamentárias.

Também foi facultado ao Presidente da República (art. 13) expedir decretos-leis sôbre as matérias da competência legislativa da União nos períodos de recesso do Parlamento ou de dissolução da Câmara dos Deputados, não compreendidas nessa autorização as seguintes matérias : modificações à Constituição, legislação eleitoral, orçamento, impcstos, instituição de monopólios, moeda, emprésti-

\footnotetext{
1 "Os que no Brasil costumam profligar (e dêste número somos nós) êsse desvio do rigor constitucional, apóiam a sua crítica na opinião dos constitucionalistas americanos... Mas, se entre nós se conhecesse o direito administrativo daquela república, veríamos que êle registra e não condena a prática, também conhecida nos Estados Unidos, das delegaçōes legislativas". (Rur BARbosa, Vitaliciedade de funcionário público. Extensão e limites da ação regulamentar do Poder Erecutivo, Rev. For., vol. 7.0, 1907, pág. 37). Ėste trabalho está reproduzido, na parte que nos interessa, em Ru Barbosa, Comentários à Constituiçäo Federal Brasileira, coligidos e ordenados por Homero PIREs, vol. III, Kio, 1933, págs. 203 e segts.

2 Olrveira Viana, O Problema da delegaça de poder, Rev. For., vol. 72, pág. 221.

3 Art. 73 da Constituição: "O Presidente da República, autoridade suprema do Estado..."
} 
mos públicos, alienação e oneração de bens imóveis da União. $O$ uso dessa competência pelo Presidente da República é condicionado às "necessidades do Estado", mas essa limitação não tem alcance jurídico, pois o juiz da necessidade é o próprio Presidente.

Por outro lado, "enquanto não se reunir o Parlamento Nacional" - diz o art. 180 - "o Presidente da República terá o poder de expedir decretos-leis sôbre tôdas as matérias da competência legislativa da União". Esta competência legislativa completa, que o Presidente ainda acumula, envolve inclusive as funções do poder constituinte, e assim tem entendido o Govêrno, que já decretou oito emendas constitucionais - "leis constitucionais", segundo a terminologia usada no art. $174, \S 4 .^{\circ}$, da Constituição.

Finalmente, o art. 12 declara que "o Presidente da República pode ser autorizado pelo Parlamento a expedir decretos-leis, mediante as condições e nos limites fixados pelo ato de autorização", e o art. 11 exige que as leis de iniciativa do Parlamento se limitem a dispor sôbre "a substância e os princípios" da matéria regulada, cabendo ao Poder Executivo expedir os "regulamentos complementares".

Quanto à competência para expedir regulàmentos, além do que dispõe o citado art. 11, consignou a Constituição a disposição genérica do art. 74, letra a : "Compete ao Presidente da República : a) sancionar, promulgar e fazer publicar as leis e expedir decretos e regulamentos para sua execução". Esta competência como adiante veremos é tradicional no nosso direito público.

Dêste rápido transunto verifica-se que a função normativa do Chefe do Estado já não se limita à expedição de regulamentos mas abrange também a competência originária para decretar leis (decretos-leis) em certas matérias. E' à luz dessas modificações introduzidas no nosso ordenamento constitucional que pretendemos estabelecer um confronto entre a lei e o regulamento.

\section{REGIME DE LEGALIDADE}

3. No moderno "Estado de direito" também chamado regime da legalidade, tôda a atividade dos cidadãos e do poder público está condicionada a normas gerais preexistentes.

Nenhum ato é legítimo senão quando conforme com as normas obrigatórias em vigor. "Ninguém pode ser obrigado a fazer, ou deixar de fazer alguma coisa, senão em virtude de lei" - dispunha o art. 72, § $1 .^{\circ}$, da nossa Constituição de 1891. A Constituição de 1934 continha idêntico dispositivo: "Ninguém será obrigado a fazer, ou deixar de fazer alguma coisa, senão em virtude de lei" (art. 113,

2). O art. $179,1 .^{\circ}$, da Constituição imperial era no mesmo sentido. A Constituição brasileira vigente não contém igual disposição, 
mas a esta se considera implícita, porque o constituinte de 1937 não aboiiu o regime da iegalidade. "A especificação das garantias e direitos acima enumerados" - diz o art. 123, referindo-se aos "direitos e garantias individuais" enumerados no art. 122 - "não exciui outras garantias e direitos, resultantes da forma de govêrno e dos princípios consignados na Constituição"4.

O regime da legalidade é uma conquista política e jurídica da consciencia universal, traduzida no chamado Estado de direito. Como observa RADBruch, essa expressão foi muito esvaziada do seu sentido primitivo que envolvia a idéia de limitação do poder do Estado em face dos direitos naturais da pessoa humana 5. "Le but de toute association politique est la conservation des droits naturels et imprescriptibles de l'homme", proclamava a Declaração francesa de 1789. O princípio foi perdendo a sua amplitude para significar sòmente que também o Estado está limitado pelo direito positivo. A lei obriga tanto o Estado como o particular.

O regime da legalidade, tal como é modernamente conceituado, não exclui o absolutismo do Estado. Mas entre o absolutismo moderno e o antigo há esta diferença: 0 absolutismo antigo agia livremente, sem obediência a quaisquer normas (Princeps legibus solutus est), ao passo que o absolutismo dos nossos dias está condicionado a normas de aplicação genérica. A diferença não é muito grande do ponto de vista político, pois é sempre fácil decretar uma ncrma genérica para justificar o ato concreto, mas do ponto de vista jurídico dela derivam consequêencias diversas, que não podem ser desprezadas.

A simples não inclusão, no texto constitucional, do prịcípio de que ninguém pode ser obrigado a fazer ou deixar de fazer alguma coisa senão em virtude de lei, não pode significar de modo algum que tenhamos abolido o regime da legalidade e restaurado a norma do quod principi placuit legis hảbet vigotem.

4. A teoria das constituições rígidas veio reforçar consideràvelmente o regime da legalidade. Criou-se uma norma mais alta que a simples lei ordinária - a norma constitucional. Distinguiu-se

4 A Procuradoria da República argumentou com a inexistência, na Constituição atual de disposição equivalente à do art. $72, \$ 1 . "$, da de 91 , para legitimar o ato do ciretor da Central do Brasil que proibira a entrada, nas denendéncias decuela repartiçäo, de um cidadão acusado de praticar advocacia administrativa (V. Rev. For., vol. 81, pág. 592, parecer do Procurador Lufs GallotTI).

5 "Jà se tem interpretado esta sujeição minima do Estado ao seu próprio direito positiva como uma deturpação sositivista e um sisternático esvaziamonto da idéia de "Estado-de-direito" de todo o seu verdadeiro conteúdo, visto que esta segundo jâ foi observado, significava originàriamente o mesmo que a sujeição do Estado nos diteitos naturais individuais do homem e a um direito natural anterior a E Estado, (Gustav Rapbruch, Filosofia do Direito, trad. de L. CABral de Moncada, 2.n ed., São Paulo, 1937, § 26, pág. 268). 
entre poder constituinte e poder legislativo, subordinado o segundo ao primeiro. Já não é sòmente $o$ poder executivo (o govêrno, pròpriamente dito) que está subordinado à lei emanada do poder legislativo; também o poder legislativo está subordinado a uma lei superior, que é a Constituição, emanada do poder constituinte 6 . O sistema de govêrno norte-americano e os que nêle se inspiraram estabeleceram garantia efetiva para o contrôle da constitucionalidade das leis, permitindo ao Poder Judiciário deixar de aplicar as leis inconstitucionais. Não é objeto dêste trabalho o contrôle da constitucionalidade das leis. Apenas o enunciamos para encaminhar a argumentação sôbre o nosso tema, que se limita ao confronto da lei e do regulamento.

Há, pois, nos regimes de constituição rígida, ou melhor, nos regimes de supremacia da Constituição sôbre as leis, uma hierarquia das normas obrigatórias vigentes no Estado. Essa hierarquia, como é sabido, tem três graus: a) constituição; b) lei; c) regulamento7.

1. - Nessa gradação, a generalidade acompanha a obrigatoriedade. A Constituição é mais genérica do que a lei e prima sôbre ela; a lei é mais genérica que o regulamento, e está em plano superior ao dêste. Essa hierarquia corresponde à hierarquia entre os poderes constituinte, legislativo e executivo. Assim como o executivo está subordinado ao legislativo e êste ao constituinte, também o regulamento, expedido pelo executivo, está subordinado à lei, elaborada pelo legislativo, do mesmo modo que a lei está subordinada à constituição, formulada pelo poder constituinte.

Apresentada a questão por esta forma, não oferece, à primeira vista, dificuldades apreciáveis. Mas estas surgem quando se indaga, em face de um texto determinado, se se trata de regulamento ou de lei.

\section{DISTINÇÃo ENTRE LEI E REGULAMENTO}

\section{Opinióes de Hautiou e Duguit}

5. Em primeiro lugar: a lei pode distinguir-se do regulamento pelo seu conteúdo? Em outras palavras, há uma matéria específica do regulamento e uma matéria específica da lei?

A questão é controvertida. HAURIou responde afirmativamente : há uma matéria própria do regulamento e uma matéria própria da lei. A distinção entre uma e outra pode fazer-se pesquisando-se

6 Consulte-se A. EsMerN Eléments de droit constitutionnel français et comparé 8. a ed., revista por HENRY NEZARD, tomo I, Paris, 1927, I parte, tít. II, cap. V ("La théorie des constitutions écrites").

7. Cfr. Quelnós LIMA, Princípios de sociologia jurídica, Rio, 1922, §§ 152 e segts. 
o que êle chama o espirito do regulamento e o espirito da lei: "Nous savons que la matière propre du règlement réside dans son ESPRTT et qu'il y a un esprit du règlement comme il y a un lesprit de la loi. Cet esprit consiste à poser des règles qui sont pour l'organisation et ie maintien de íordre et à les paser seion les vues autoritaires du poutvoir politique. Ainsi, d'une part, le contenu des règles règlementaires n'est pas nécessairement tiré de la nature des chases, il est surtout déterminé "a priori" par la nécessité de procéder à l'organisation hâtive de certains rapports sociaux ou pat celle de mettre rapidement fin, par n'importe quel moyen, à certains troubles qui menacent l'ordre social. D'autre part, ces règles improvisées ne sont point pénétrées de l'esprit de liberté qui est propre à la loi; elles sont au contraire pénétrées de l'esprit d'autorité qui est propre au pourvoir politique et, en principe, elles ne laissent pas aux intéressés le choix des moyens d'exécution"' 8 .

Os critérios de Hauriou são, como se vê, muito imprecisos. A sua argumentação visa sobretudo à demonstração de que o regulamento é ato administrativo e não ato legislativo, tendo em vista principalmente que, na França, os órgãos judicantes não podem declarar a inconstitucionalidade das leis, mas podem deixar de aplicar os regulamentos eivados de excesso de poder ou de ilegalidade.

E claro que, de um ponto de vista puramente teórico, sempre é possível traçar as lindes da matéria que deve caber ao regulamento e da que deve tocar às leis. Do mesmo modo se pode estabelecer fronteira entre a matéria constitucional e a matéria legal. Mas, qualquer que seja o critério teórico adotado, será sempre impreciso, e as controvérsias não terão fim. Mesmo que as regras de distinção fôssem consignadas em leis ou no texto constitucional, ainda assim teriam de ser de tal modo genéricas que suscitariam na prática dificuldades insuperáveis. Por isso é que o critério substancial de distinção não oferece as mesmas garantias de certeza de critério formal.

O mesmo problema tem cabimento na definição da matéria constitucional. Embora se possa dizer teòricamente em que devam consistir, do ponto de vista substancial, as normas constitucionais, é sempre preferivel considerar constitucionais tôdas as normas, qualquer que seja o seu conteúdo, consubstanciadas na Constituição.

A nossa Constituição do Império havia estabelecido um critério de distinção material e não apenas formal, ao dizer no seu art. 178: "E só constitucional o que diz respeito aos limites e atribuições respectivas dos Poderes Políticos, e aos direitos politicos e individuais dos cidadãos". Tưo o que não fôsse constitucional poderia ser re-

8 Maurice Hauriou, Précis de droit administratif et de droit public, 8." ed., Paris, 1914, pág. 54. 
formado pela lei ordinária, isto ê, sem as formaliđadès especiaís exigidas para reforma da Constituição. Mas êsse sistema não dá bons resultados. A diferença estabelecida pela Constituição acaba por diluir a rigidez do texto constitucional.

As nossas Constituições republicanas seguiram orientação diversa, considerando constitucionais tôdas as disposições da Constituição, sem atender ao seu conteúdo 9. Esse critério formal tem grande vantagem, como observa Hermann Heller: "O conceito de Constituição formal é cientificamente necessário, porque nunca pode haver coincidência perfeita entre a Constituição material e a formal. Os textos constitucionais têm, certamente, conteúdos típicos, mas não existem princípios teóricos que determinem o que se deve reservar à lei constitucional. Sôbre o que deve ser regulado pelo texto constitucional decidem, como em geral sôbre o que deve ficar reservado à lei, a tradição, a conveniência politica, a situação de poder e a consciência jurídica" 10 . Em suma, quem decide da matéria constitucional é o poder constituinte. Do mesmo modo, quem decidirá da matéria legal é o poder legislativo, respeitadas as normas existentes na Constituição.

Esse conceito formal de constituição, lei e regulamento é muito fértil para os estudos jurídicos, porque permite estabelecer uma hierarquia perfeita entre regulamento, lei e constituição, reduzindo ao mínimo as controvérsias possíveis.

Daí a grande valia da distinção feita por Dugurr entre o ponto de vista formal e o substancial para qualificação dos regulamentos. Para êle, o regulamento, do ponto de vista substancial ou material, é lei, porque contém as características comuns às leis. Do ponto de vista formal, entretanto, é ato administrativo, subordinado, pois, ao contrôle da sua legalidade : "O que melhor demonstra a exatidão da nossa tese e confirma que estamos certos é a perplexidade e embaraço dos autores que combatemos quando se encontram em face de uma organização, a organização de um ministério, por exemplo, regida ao mesmo tempo por uma lei e por um regulamento. O conteúdo da lei e do regulamento é, em tal caso, exatamente o mesmo; para ser lógico, deveria dizer-se que a lei e o regulamento são, uma e outro, atos administrativos. Entretanto, ninguém se atreve a dizer que essa lei orgânica não seja uma lei material; portanto, êsse regulamento orgânico, que tem o mesmo conteúdo, é também, do pontó de vista material, um ato legislativo" 11 .

9 Não obstante, a Const. de 1934 estabeleceu uma diferença entre "emenda" "revisão" constitucional, esta Gitima de processo mais simples que a primeira. Mas tevę a precaução de indicar formalmente os dispositivos cuja alteração importaria "emenda" 1942. pág. 305.

10 Hermanin HrLler, Teoria del Estado, versão esp. de Lvís Tozfo, México, 1942. pág. 305 .

11 Lton Dugurt, Manuel de droit constitutionnel, 3.^ ed., Paris, n.` 34, pág. 107. 
A distinção entre lei materiêl e lei fơmal, que esclarece o trecho antericr reiativo aos reguiamentos, é a seguinte : "Do ponto de vista formal, é lei tôda decisão emanada do órgão que, segundo a Constituição do país a que se refira, tem o caráter de órgão legislativo". "Do ponto de vista material, a lei é o ato pelo qual o Estado formula uma regra de direito objetivo ou estabelece regras, ou organiza instituições destinadas a assegurar o cumprimento de uma regra de direito objetivo".

A distinção entre o critério formal e o critério material é fértil para o jurista, porque a hierarquia existente entre lei e regulamento, assim como entre constituição e lei, é só de natureza formal. Para que o regulamento seja invalidado é preciso que contrarie disposições de uma lei formal; para que as leis deixem de ser aplicadas é necessário que ofendam disposiçōes do texto constitucional.

\section{Distinção formal pela indicação da competência}

6. Nos regimes das nossas Constituições anteriores, o problema era simplificado, porque o poder legislativo competia na sua totalidade às câmaras, com a sanção do Chefe do Estado, ou mesmo sem ela, nos casos de remoção do veto. Portanto, lei formal eram as normas emanadas das câmaras, através do processo competente. Nem todos os atos praticados pelas câmaras eram leis, pois alguns havia de natureza judicial, outros de natureza administrativa (reconhecimento de mandatos, etc.), mas não é êste o ponto que nos interessa. Estamos tratando dos atos de conteúdo genérico, de aplicação geral, os atos pròpriamente normativos, que se praticavam segundo um processo predeterminado e, assim, adquiriam a fôrça de lei formal. Estes atos emanavam das câmaras no seu caráter de poder legislativo.

A coincidência mais ou menos perfeita que entre nós havia entre as funções do Estado (poderes) e os órgãos incumbidos de cada uma dessas funções facilitava a solução do problema. A função legislativa - poder legislativo - era incumbida precìpuamente às câmaras; a função executiva - poder executivo - ao Chefe do Estado, e as funções judiciárias - poder judiciário - aos juízes e tribunais. Esta a idéia de Montesouieu. Embora aquêle pensador não houvesse distinguido claramente entre função e órgão ${ }^{1 \%}$, resulta do exame de sua obra que uma mesma autoridade não deveria exercer mais de uma função 13 .

$12 R$ KraneneUng, Teoria politica, versio esp de Juan Pazant, Mérico, 1814, pág. 51 : "Locke $Y$ Mon'Tesquieu cometen el mismo erró terminológico al no distinguir propriamente entre la función y ei órgano. .

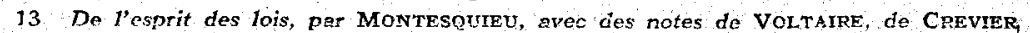
DE MABLY, DE LA HARPE, etc., nouvelle édition revue sur les meilleurs teries, Paris, Gamier, Livro XI, cap. VI, pág- 143. 
A Constituição atual torna o problema menos simples, parque à tripartição das funções, inerente ao Estado, não corresponde, no mesmo grau que nas constituições anteriores, uma tripartição de órgãos. Isto é sobretudo evidente no que respeita à função legislativa, que foi repartida entre o Parlamento e o Presidente da República, podendo ser eventualmente conferida, em certas matérias, ao Conselho da Economia Nacional mediante plebiscito.

7. Não havendo, pois, na Constituição vigente, um único órgão legislativo, a classificação de uma determinada norma como lei formal não pode ser feita em consideração do órgão de que emana, mas tendo-se em vista a competência em virtude da qual age o órgão, ao editá-la. Continua verdadeira a asserção de que le: é a norma que emana do poder legislativo, mas poder legislativo não significa neste caso um órgão específico, mas uma competência constitucional.

O mesmo raciocínio se poderia fazer em relação à legislação delegada no regime das Constituições de 1824 e 1891. Mas, com referência à legislação delegada, não seria êle de todo verdadeiro, pelo menos no rigor teórico, pois o ato de delegação, que conferia valor legal formal à lei elaborada em virtude dêle, também havia emanado de um órgão específico (as câmaras). O poder executivo ao fazer a lei delegada, invocav́a a competência instituída na lei de delegação, mas esta havia emanado do órgão legislativo. A natureza do órgão tinha, pois, valor decisivo na caracterização da norma como legal ou regulamentar. Hoje em dia, como o Presidente da República pode legislar por atribuição originária independentemente de delegação, o critério a adotar não pode ser mais o do órgão que expede a norma, mas o da competência em virtude da qual êsse órgão atua.

8. A denominação do ato também é de importância no regime atual, pois a Constituição adota uma nomenclatura diferenciada :

a) para as emendas constitucionais, usa o têrmo lei constitucional (art. 174, $\$ 4 .^{\circ}$ );

b) para as leis emanadas do Parlamento, usa a palavra lei (arts. 64 e 66; 11 e 74, a);

c) para as leis emanadas do Presidente da República, seja por competência originária, seja por competência delegada, emprega o vccábulo decreto-lei (arts. 12, 13, 14 e 74, b);

d) para os regulamentos serve-se das palavras decreto, regulamento e da expressão regulamento complementar (arts. $11 \mathrm{e}$ $74, a)$.

O valor formal da lei é exatamente igual ao do decreto-lei, pois uma e outro resultam do exercício do poder legislativo. 
No caso das emendas constitucionais, que têm sido promulgadas pelo Presidente da República no uso das atribuições do art. 180 da Constituição, a denominação é o único elemento formal de que dispõe o intérprete para saber se se trata de lei ordinária ou de lei constitucional, pois é aquêle mesmo dispositivo que tem fundamentado a competência do Presidente da República para exercer, na sua plenitude, as atribuiçóes legisiativas do Parlamento, até que êste seja instalado e entre a funcionar. A invocação simultânea do citado art. 180 e do art. 174, que se refere às emendas constitucionais, seria aconselhável, para não ficar a natureza e o alcance de uma reforma da Constituição na dependência exclusiva do nome que se lhe dá.

No tocante, porém, à distinção entre lei e regulamento, isto é; para se saber se o Presidente da República, podendo expedir sôbre o mesmo assunto um decreto-lei ou um mero regulamento, promulgou uma norma legal ou uma simples norma regulamentar, é imprescindível a invocação da competência constitucional. Se o Presidente expede normas com fundamento nos arts. 11 ou 74, a, essas normas serão consideradas apenas regulamentares e a sua obrigatoriedade fica na dependência de confronto com as disposições legais em vigor. Se, entretanto, a competência invocada fôr a dos artigos $12,13,14$ e 180, teremos então normas legais, cuja aplicação só poderá ser negada por motivo de inconstitucionalidade.

Os regulamentos são expedidos mediante decreto, pois o decreto é a denominação genérica do ato praticado pelo chefe do poder executivo. Sendo o regulamento um ato do poder executivo no sentido formal, a sua expedição é feita por decreto. Entre nós, a forma tradicional é redigir o regulamento em texto separado e baixar-se um decreto que o aprova, mas nada impede que o texto seja um só, isto é, que os preceitos do regulamento estejam consubstanciados no próprio decreto, como já se vem observando em alguns casos, entre os quais se pode citar o Decreto $n^{\circ} 4.857$, de 9 de setembro de 1939, que dispôs sôbre a execução dos serviços concernentes acs registros públicos estabelecidos pelo Código Civil. PoNTEs DE MiRanda acha preferível esta última prática, para comodidade das citações 14 .

Já temos, porém, exemplo de regulamento expedido por decreto-lei, o que constitui sem dúvida técnica viciosa. Trata-se do Decreto-lei n. 1.230 , de 29 de abril de 1939, que "expede o Regulamento para execução dos Decretos-leis ns. 1.002 , de 29 de dezembro de 1938, e 1.172, de 27 de março de 1939" (legislação especial para resgate de divida dos agricultores). No preâmbulo, diz êsse 
soi-disant regulamento: "O Presidente da Repúbtica, usando da faculdade que lhe confere 0 art 180 da Constituição Federal, resolve aprovar e expedir com fôrça de lei o regulamento... que a êste acompanha, assinado pelo Ministro de Estado dos Negócios da Fazenda". Não se trata, pois, de um regulamento, no sentido tradicional do têrmo, mas de uma lei. Regulamento com fôrça da lei é um ilogismo. Esse exemplo de técnica defeituosa corrobora a afirmação anterior de que a invocação da competência tem importância fundamental. $O$ aludido regulamento foi baixado segundo as atribuições conferidas ao Presidente pelo art. 180 da Constituição, isto é, atribuições legislativas e não regulamentares. O nome de regulamento, que the foi dado, é como se não estivesse escrito, pois o que se tem é uma lei. Se, em vez de ter sido invocada a competência do art. 180 , tivesse sido indicada a do art. 74 , a, então, teríamos de fato um regulamento e pouco importaria que, por equívoco, se lhe tivesse apôsto o nome de decreto-lei. A menção da competência é que deve prevalecer, pois lei é ato do poder legislativo e poder legislativo não é, pela atual Constituição, um órgão determinado, mas uma competência constitucional que pertence a mais de um órgão.

\section{Sobrevivência da hierarquia entre lei e regulamento}

Essas considerações são de importância para deixar bem claro que, mesmo no sistema da Constituição atual, e principalmente tendo em vista o exercício total da função legislativa conferida transitòriamente ao Presidente da República pelo seu art. 180, subsiste entre nós a distinção formal entre regulamento e lei, como atos de categoria diferente e valor diverso, subordinadas que estão as normas regulamentares aos preceitos legais. A identidade do órgão que expede umas e outras não basta para desfazer a diferenciação, porque não é a natureza do órgão mas a competência ou qualidade em que age que deve prevalecer.

Admitir o contrário importa completa subversão da ordem jurídica. O sistema da legalidade, o Estado de direito teria desaparecido entre nós, e o Presidente da República estaria equiparado aos imperantes das antigas monarquias absolutas: Princeps legibus solutus est. Esta conseqüência repugna, porém, não só à consciência jurídica moderna, como ainda ao próprio texto constitucional .

Se não houvesse diferença entre lei e regulamento, a Constituição não falaria de uma e outro usando denominações diversas. E não haveria também diferença entre lei e ato administrativo específico (demissão, aposentadoria, etc.), desde que praticado o ato pelo Chefe do Estado. As ações contra a União, com fundamento em ato presidencial, não seriam possíveis, com o que se limitaria indevidamente o disposto no art. 180 da Constituiçāo. 
E' preciso ir mais longe ainda : como o Presidente acumula presentemente a função constituinte, podendo emendar a Constituição, também não haveria possibilidade de ser qualquer ato seu declarado inconstitucional pelo poder judiciário, o que aberra do disposto no art. 96 da Carta de 10 de novembro, que prevê a declaração da inconstitucionalidade de ato presidencial. E também seria letra morta a disposição do art. 85 , que define os crimes de responsabilidade do Chefe do Estado, pois os seus atos seriam sempre legítimos, mesmo ofendendo as leis ou a Constituição. Pelo simples fato de acumular o Presidente funções legislativas, estaria, ao agir como poder executivo e não como poder legislativo, absolvido das leis; e por acumular transitòriamente o poder constituinte, estaria igualmente absolvido da Constituição. E chegariamos a concluir ainda que os atos praticados, pelo Chefe do Estado, como simples cidadão, também seriam intangíveis, pois a pessoa do cidadấo e a do Presidente é uma só...

Tais conseqüências mostram que o princípio da identificação do regulamento com a lei, do ponto de vista da sua obrigatoriedade, é inadmissível até no sistema da atual Constituição. Subsiste, entre nós, o regime da legalidade : subsiste, portanto, a hierarquia das normas emanadas do poder público. O regulamento é subordinado à lei, assim como a lei é subordinada à Constituição 15. Pouco importa que um só órgão - o Presidente da República - tenha editado, ao mesmo tempo, uma emenda constitucional, um decreto-lei ou um regulamento. A hierarquia prevalece, porque diverge a competência constitucional em virtude da qual o Presidente emenda a Constituição, decreta leis ou expede regulamentos.

\section{Matéria dos regulamentos}

10. Nem sempre é fácil saber se, ao ter de regular um assunto, deve o Presidente expedir um decreto-lei ou um regulamento. E não há um critério rígido para resolver a questão, tendo-se em vista a matéria a ser regulada.

Em alguns casos, a Constituição fornece o roteiro. Por exemplo: se se trata de reorganizar o govêrno ou a administração federal, ou dispor sôbre o comando supremo e a organização das fôrças armadas, a matéria é de lei e não de regulamento, nos têrmos do art. 14 da Constituição. As restrições dos direitos e garantias individuais, permitidas nos vários incisos do art. 122, também devem ser objeto de lei. 15 A subordinação do regulamento à lei está consubstanciada no princípio legal
de que uma lei só se revoga por outra lei : "Não se destinando a vigéncia temporária, a lei terá vigor até que outra a modifinive ou revogue" (art. $20^{\circ}$ da Lế de Introduçãó ao Código Civil, Decreto-1ei n. 4.657 , de 4-9-1942). 0 art. 4.0 da Introdução ao Código Civil era mais eloqüente, embora de alcance igual; "A lei só se revoga, ou derroga, por outra lei..." 
Enfim, sempre que a Constituiçãa, ao dispor sôbre đeterminađo assunto, exigir a feitura de uma lei, a matéria é legal e não regulamentar. Como exemplos, podemos citar, além de outros, os artigos $2 .^{\circ}$ (uso de símbolos nacionais); $5 .^{\circ}$ (incorporação, subdivisão e desmembramento de Estados); $6 .^{\circ}, 8^{\circ}$, parágrafo único, e 31 (criação e administração dos territórios); 16 (que enumera as matérias da competência legislativa da União); 17 (autorização aos Estados para legislar supletivamente); 19 (execução de serviços federais pelos Estados); 20 (impostos); 32, parágrafo único (isenção tributária para serviços públicos concedidos); 63 (organização de plebiscito para outorgar funções legislativas ao Conselho da Economia Nacional); 67 a 72 (matéria orçamentária); 85 (definição dos crimes de responsabilidade do Presidente da República), 97, parágrafo único (elevação do número de juízes do Supremo Tribunal $\mathbf{F e}$ deral); 111 (extensão do fôro militar a civis); 112 (instituição de tribunais e juízos militares); 114 (organização do Tribunal de Contas e de suas delegações); 120 (requisição de direitos políticos); $143, \S 2 .^{\circ}$ (condições para que os Estados possam exercer atribuições relativas a concessão ou autorização para exploração de minas e quedas d'água); 141 (nacionalização de minas, jazidas minerais e quedas d'água); 145 (concessão de prazo para nacionalização de bancos de depósito e emprêsas de seguros); 146 (normas para fiscalização e revisão das tarifas de serviços públicos concedidos); 153 (fixação de percentagem obrigatória de brasileiros em serviços públicos concedidos ou em emprêsas industriais e comerciais); 156 (estatuto dos funcionários públicos); 160 (estatuto dos militares de terra e mar); 160, parágrafo único (condições para ser o militar declarado indigno do oficialato); 164 (serviço militar ou outros encargos necessários à defesa da pátria); 165 (nacionalização das indústrias situadas na faixa das fronteiras); 171 (justiça e processo especiais para os crimes contra o Estado); etc.

As indicações acima não são, porém, suficientes para saber se determinada matéria deve ser regulada em lei ou em regulamento. O exame dos textos constitucionais em cada caso concreto é indispensável, porque, como se viu, determinadas providências não podem ser tomadas senão em virtude de lei e, se a respeito delas não há lei anterior que possa ser regulamentada, qualquer disposição sôbre o assunto tem de ser adotada em lei formal. $O$ regulamento que dêle tratasse seria nulo por motivo, já não de ilegalidade, mas de inconstitucionalidade, porque não poderia suprir a lei onde a Constituição a exige. $\mathbf{E}$ o regulamento que, por êsse motivo, fôsse declarado inconstitucional pelo poder judiciário, não poderia ser confirmado pelo parlamento, nos têrmos do art. 96, parágrafo único, para efeito de ficar removida a inconstitucionalidade. Esse recurso 
só é permitido nas declaraçũes de inconstitucionaiidade de lei ou decreto-lei (no sentido formai), e não de ato do Presidente da República, como é o regulamento.

Mas, se é imprescindível o exame dos textos constitucionais em cada caso concreto, para saber se a matéria pode ser tratada em regulamento, ou se é indispensável que se faça lei a respeito, não é contudo suficiente êsse exame. $\mathbf{E}$ não o é porque o mesmo conteúdo pode ser simultâneamente objeto de lei e de regulamento.

Para saber se, ao regular determinado assunto, pode o Estado expedir regulamento, em vez de lei, cumpre ainda examinar tôdas as disposições legais vigentes sôbre aquêle assunto. Essa verificação é indispensável, porque, estando o regulamento abaixo da lei, seria inoperante qualquer disposição regulamentar que entrasse em conflito com qualquer dos princípios legais vigentes.

No tocante às leis do Govêrno Provisório, instituído em 1930, êsse exame tem de ser ainda mais cuidadoso, porque os atos, tanto legislativos como regulamentares, eram expedidos mediante decretos, e não havia na chamada "Lei orgânica do Grovệrno Provisório" (Decreto n. 19.398 , de 11 de novembro de 1930) disposições especiais instituindo uma a competência legislativa e outra a competência regulamentar. Além disso, a numeração dos decretos era seguida, quer se tratasse de lei, quer se tratasse de regulamento.

Se o intuito do poder público é alterar alguma das disposições legais em vigor, está obrigado a servir-se đa lei formal, não the bastando para isso o regulamento. Se, ao contrário, apenas pretende facilitar a execução da lei, especificá-la de modo mais inteligivel, sem contudo dispensar exigências que ela faz ou exigir mais do que ela pede, então o regulamento é o veículo apropriado e tècnicamente aconselhável.

A pretexto de facilitar a execução da lei, não pode, entretanto, o regulamento pretender fixar-1he a interpretação de maneira conclusiva. Semelhante intuito não poderia jamais obrigar o poder judiciário, que é o intérprete autorizado da lei, no julgamento dos casos concretos que the são submetidos. $O$ regulamento interpretativo valerá, pois, como subsídio doutrinário valioso e qualificado, mas não terá fôrça obrigatória nem para os particulares, que poderão recorrer às vias judiciais, nem para os juízes, que poderão deixar de aplicá-lo por entenderem que contraria disposição legal vigente.

A interpretação da lei só é obrigatória quando autêntica, isto é, quando feita por outra lei. Mesmo assim, muitos autores entendem que o caso não é de interpretação, mas de formulação de regra nova, 
mais explícita, que se aplica obrigatòriamente não por ser interpretativa, mas precisamente por ter fôrça de lei formal 16.

\section{Execução provisória de tratados}

11. Além dos arts. 13 e 14 da Constituição, que conferem competencia legislativa originária ao Presidente da República, nas matérias que especificam, também deve ser considerada dessa natureza a faculdade contida no art. $74, n$ : "Compete privativamente ao Presidente da República... determinar que entrem provisòriamente em execução, antes de aprovados pelo Parlamento, os tratados ou convenções internacionais, se a isto o aconselharem os interêsses do país".

Trata-se aqui de competência legislativa, porque o tratado tem fôrça igual ao da lei. Não é nosso propósito, no presente trabalho, discutir as difíceis questões que os tratados suscitam. Não pode, entretanto, ser pôsto em dúvida que o tratado em vigor vale como lei : "Às leis nacionais equiparam-se os tratados. Do ponto de vista do direito interno de cada país, os tratados, diz DESPAGNET, desde que ratificados e aprovados, são verdadeiras leis, derrogam o direito comum e podem autorizar o recurso em cassação" 17 .

Ora, o art. 75, n, da Constituição faculta ao Presidente determinar a execução provisória dos tratados, ad referendum do Parlamento. Isto equivale a pô-los em vigor. Se, mais tarde, forem ratificados pelo Parlamento, essa ratificação retroage à data da sua aprovação pelo Chefe do Estado. Se o não forem, fica revogada a aprovação, parecendo, porém, que ficarão ressalvados os atos consumados e os direitos adquiridos na vigência da sua execução provisória, salvo se uma lei retroativa dispuser o contrário.

E', pois, o dispositivo em exame, uma fonte de competência legislativa originária do Presidente, embora o seu ato possa vir a ser revogado. Essa condição, aliás, não importa muito, porque qualquer lei emanada do Presidente da República pode vir a ser revogada pelo Parlamento. Não se excetuam nem os decretos-leis previstos no art. 14 (organização do govêrno e da administração federal, comando supremo e organização das fôrças armadas), pois a faculdade ali conferida ao Chefe do Estado de legislar sôbre a matéria não é privativa, mas cumulativa. O advérbio livremente, usado no texto, não significa privativamente, nem exclusivamente; significa sòmente que o Presidente, para expedir aquêles decretos-leis, não depende do Parlamento, mas isso não exclui o poder do Parlamento de os revogar.

16 Cfr. Carlos Maxmmlano, Hermenêutica e aplicação do direito, Pôrto Alegre, 1925 , § 95, pág. 102 .

17 Castro Nunks, Tooria e prática do Poder Judiciário, ed. Rev. For., Rio, 1943, pág. 320 . 


\section{O Conselho da Economia Nacional}

12. Mais discutivel, porém, é a faculdade conferida ao Conselho da Economia Nacional, mediante aprovação do Presidente da República, nos arts. 61, $b$, e c, e 62. Dizem èsses dispositivos:

"São atribuições do Conselho da Economia Nacional .... b) estabelecer normas relativas à assistência prestada pelas asscciaçôes, sindicatos ou institutos; c) editar normas reguladoras dos contratos coletivos de trabalho entre os sindicatos da mesma categoria da profissão ou entre associaçōes representativas de duas ou mais categorias". Essas normas "só se tornarão obrigatórias mediante aprovação do Presidente da República".

O desembargador SEABRA Fagundes entende que se trata, no caso, de função legislativa 18. Quer-nos parecer, porém, que a atribuição de que tratam os dispositivos em exame é de natureza regulamentar.

Em primeiro lugar, não se compreende que a Constituição, havendo usado, em outros dispositivos, com impressionante uniformidade, as designações de lei e decreto-lei para designar as disposiçôes de caráter legal, fôsse empregar o têrmo norma no mesmo sentido e com o mesmo alcance de lei e decreto-lei.

Além disso, como se vê do art. 63, o Conselho da Economia Nacional só poderá ter "pođeres de legislação sôbre algumas ou tôdas as matérias de sua competência", quando assim resolver o povo em plebiscito especial. Não é lógico que, tendo a Constituição exigido a sanção presidencial para a legislação emanada do Parlamento, que é órgão legislativo por fôrça da própria Constituição, pretendesse dispensar a sanção presidencial, quando mais tarde se viesse a atribuir função legislativa ao Conselho da Economia Nacional. E' de se supor, portanto, que a sanção presidencial será exigida, quando tais poderes legislativos forem outorgados, mediante plebiscito, àquele órgão de representação profissional. Portanto, enquanto tal plebiscito não se realizar, e com resultado favorável, não se deve entender que as normas que, ordinàriamente, pode o Conselho editar, mediante aprovação do Presidente, sejam desde já normas legislativas, isto é, leis no sentido formal.

Além disso, como se vê da enumeração contida no art. 61, o Conselho colabora na elaboração das leis incumbidas ao Parlamento e que interessem à produção nacional (letra $d$ ). Idêntica colaboração presta êle ao Presidente da República, quando tiver êste de expedir decretos-leis sôbre as mesmas matérias, nos perí-

18 MrCuEl. SEAERA FAGUNDEs, $O$ contrôle dos atos ziministrafivos pelo poder judiciário, Rio, 1941, pág. 28, nota 1 : "De colaboração com o Conselho da Economia Nacional pode o presidente converter em texto de lei normas que aquêle elabore..."

PONTES DE MIRANDA näo deixa bem claro o seu pensamento a respeito (Comentários à Constituiçäo Federal de 10 de novembro de 1937 , vol. I, Rio, 1938, págs. 326 e 327 ). 
dos de recesso do parlamento ou de dissolução da Câmara dos Deputados (art. 13, parágrafo único). Portanto, quando se trata de lei, seja do Parlamento, seja do Presidente, a colaboração do Conselho já está prevista em disposições outras, sendo de concluir-se, por conseguinte, que os arts. 61 , b e c, e 62 tratam da colaboração do Conselho com o Presidente, não em matéria legislativa, mas em matéria regulamentar. A colaboração do Conselho é, portanto, ou de natureza legislativa, nos casos do art. $61, d$, e do art. 13, parágrafo único, ou de natureza regulamentar, nos casos do art. $61, b$ e c, e art. 62 .

À mesma conclusão nos leva o exame do art. 38 , que define o poder legislativo: "O Poder Legislativo é exercido pelo Parlamento Nacional, com a colaboração do Conselho da Economia Nacional e do Presidente da República, daquele mediante parecer nas matérias de sua competência consultiva e dêste pela iniciativa e sanção dos projetos de lei e promulgação dos decretos-leis autorizados nesta Constituição".

Dêsse dispositivo se vê :

1) que o Conselho da Economia Nacional colabora na tarefa legislativa, emitindo parecer e não formulando normas, e de tais pareceres cogitam exatamente o art. 61, $d$ (legislação do Parlamento), e 13, parágrafo único (legislação do Presidente);

2) que o Presidente, ou colabora com o Parlamento na tarefa legislativa, cu exerce êle próprio o poder legislativo, mas pela "promulgação dos decretos-leis autorizados" da Constituição e não pela aprovação de normas formuladas pelo Conselho da Economia Nacional ;

3) que sòmente são órgãos legislativos o Parlamento e o Presidente, não estando o Conselho incluido; ora, as normas de que tratamos, embora tenham de ser aprovadas pelo Presidente, não são elaboradas por êste, mas pelo próprio Conselho, e o Presidente apenas as aprova, do mesmo modo que sanciona as leis; trata-se, pois, de atribuição do Conselho, e não do Presidente, mas o Conselho só terá funções legislativas depois do plebiscito a que se refere o artigo 63 .

Pelos motivos acima aduzidos, somos de opinião que as normas elaboradas pelo Conselho da Economia Nacional e aprovadas pelo Presidente da República são de natureza regulamentar e não legal. E' esta, aliás, a opinião autorizada do ex-ministro Francisco Campos 19. Por essa razão, estão por igual subordinadas às leis, cujas disposições não poderão contrariar.

19 “... as normas de competência do Conselho, a que se referem as citadas letras $b$ e c do art. 61 , recaem no domínio do regulamento... Por conseguinte, em relação a essas matérias o Conselho não exerce nenhuma função de caráter legislativo..." ( $O$ Estado Nacional, 3.^ ed., Rio, 1941, pág. 86). 


\section{CLASSIFICAÇÃo E APLICAÇÃo DOS REGULÂMENTOS}

13. Os autores costumam distinguir três espécies de regulamentos: regulamentos independentes, regulamentos de execução, regulamentos delegados. São de RUI BARBosA estas palavras: "GNEIST, o grande mestre, na sua grande obra de direito administrativo, divide as manifestações da atribuição regulamentar em três ramos : decretos independentes, em que o poder executivo obra sôbre si nos vários domínios constitucionais da administração pública, ainda não ocupados pela legislação; decretos executivos, cujo objeto é a aplicação de normas gerais, 'enunciadas nas leis; decretos autorizados por deliberação legislativa especial. (L'amministraz. e il dirit. amministr. inglese, trad. ital., v. I, p. 125)" 20

a) - Os regulamentos chamados de execução são os que a atual Constituição prevê no art. 74, $a$ : "Compete privativamente ao Presidente da República... sancionar, promulgar e fazer publicar as leis e expedir decretos e regulamentos para sua execução" ${ }^{21}$. Para expedir tais regulamentos, não necessita o poder executivo de cláusula legislativa especial que lho autorize. Trata-se de uma competência constitucional genérica e originária. A esta espécie de regulamento aplica-se integralmente o princípio da sua subordinação à lei. Qualquer de suas disposições que ofenda dispositivo da lei a que o mesmo se refere ou de qualquer outra lei, não pode ter aplicação.

b) Essa verificação de legalidade não pode, entretanto, ser tão rigorosa relativamente aos regulamentos autorizados ou delegados. E' comum conterem as leis disposição que confere ao poder executivo a atribuição de expedir-lhe o respectivo regulamento. $O$ julgamento da legalidade dos regulamentos dêsse tipo depende essencialmente do alcance dos têrmos da autorização.

Se a autorização contida na lei é pura e simples, isto é, apenas para expedir o regulamento necessário à sua aplicação, então o contrôle da legalidade do regulamento, que fôr baixado, há de ser tão rigoroso como o dos regulamentos chamados de execução e decretados independentemente de cláusula legislativa especial que os autorize. E' que, em tais casos, a disposição legal autorizativa é inteiramente inócua, porque apenas reproduz a atribuição constitucional originária e genérica do poder executivo para regulamentar as leis.

\footnotetext{
20 Trabalho cit., na Rev. For., vol. 7, 1907, pág. 36.

21 A competencia regulamentar do executivo e tradicional no nosso direito público:

- Const. imperial : "São suas principais atribuiçöes (do chefe do poder executi(o) expedir os decretos, instruçöes e regulamentos adequados a boa exccução das leis', $\left(\right.$ art. $\left.102,12 .^{\circ}\right)$.

- Const de 1891 : "Compete privativamente ao Presidente da República... expedir decretos, instruçōes e regulamentos para sua fiel execuçăo" (das leis) (art. 48, 1).

- Const. de 1934 : "Compete privativamente a Presidente da República..... expedir decretos e regulamentos para a sua fiel execuçäo' (das (leis) (art. 56, $1 .^{\circ}$ ).
} 
Com ela nada se acrescenta à competência já outorgada pelo texto constitucional. Ainda que determinada lei nâo contenha semelhante disposição, o regulamento pode ser baixado do mesmo modo, com fundamento exclusivo no art. 74, a, da Constituição.

Entretanto, se a autorização contida na lei é mais ampla, deixando certa margem de arbítrio ou discrição ao poder executivo, 0 exame da legalidade do regulamento expedido nessa coformidade terá de ser mais benevolente. ' $E$ ' que, não sendo proibida a delegação do poder legislativo, mas ao contrário permitida expressamente no texto constitucional (art. 12), as autorizações do tipo de que ora nos ocupamos são verdadeiras delegações. Se nessa delegação foi instituído um campo de ação discricicnária ao poder executivo, as disposições por êle decretadas no uso dessa discrição delegada são verdadeiras normas legais. Tais normas não poderão ser impugnadas em face de outra lei anterior, porque esta se considerará derrogada na parte em que colidir com os preceitos regulamentares contidos na delegação 22 .

Nestas circunstâncias, é, pois, imprescindível que o poder executivo, ao baixar o regulamento, invoque expressamente a disposição legal que tiver operado a delegação de que tratamos. Se no regulamento só se invoca a competência regulamentar genérica do art. 74, a, da Constituição, é de entender-se que o poder executivo não se prevaleceu da delegação contida na lei e, portanto, o regulamento expedido é de mera execução e não regulamento delegado.

Não podem, porém, os regulamentos desta espécie colidir com disposiçôes da própria lei, que os autoriza, porque a lei e o respectivo regulamento se reputam um corpo único, um texto orgânico, no qual uma das partes não deve estar em contradição com a outra. Pode ocorrer, entretanto, que a cláasula de autorização faculte ao poder executivo fixar a data em que alguma disposição da lei comece a vigorar. Neste caso, se o regulamento contém norma contrária àquela disposição e se não marcou a data do início da sua obrigatoriedade, prevalece o regulamento; é que, nesta hipótese, não ocorre colisão, pois a norma legal ainda não obriga, é como se ainda não estivesse escrita 23 .

22 Suponhamos que uma lei enumere taxativamente os casos em que pode o funcionário público ser demitido. Uma nova lei, regulando a matéria, contém disposição expressa, declarando que o regulamento estabelecerá os casos de demissão de funcionário.

Não pode êsse regulamento, expressamente autorizado, adotar enumeração diversa da contida na lei anterior? Claro que sirn A revogação da iei anterior terá sido operada em virtude do regulamento, mas não por fôrça dêle e sim por fôrça da lei nova:

23 Exemplo de disposição legal de vigência subordinada ao regulamento e, a mesmo tempo, conferindo delegação do executivo é o Decreto-lei n.o 1 .523, de 18-8-1939, referente a um dos artigos da Lei do Serviço Militar : "O direito a perceber $2 / 3$ doa vencimentos ou remuneraçôes, previsto no art. 224 do Decreto-lei n. ${ }^{\circ} 1.187$, de 4 de abril de 1939, só será assegurado ao empregado, operário ou trabalhador nacional, quande entrar em vigor o regulamento da nova Lei do Serviço Militar, e de acôrdo com o que nêle se dispuser". 
Em resumo: se a autorização para expedir regulamento, contida em qualquer lei, confere certo campo de ação discricionária ao poder 'executivo, a verificação da legalidade das normas regulamentares que forem expedidas na conformidade dela depende do exame dos limites da cláusula de delegação. Se foi baixado dentro dêsses limites, o regulamento é válido; se os excedeu, não é aplicável nas - disposições que os transpuseram. Também se consideram limites as demais cláusulas da mesma lei que confere a autorização, dada a exigência de que a lei e o regulamento formem um corpo sistemático, sem contradições intrínsecas.

Os critérios. são idênticos aos que vigoram em relação à legislação delegada, pois é de delegação que se trata no caso que examinamos. Assim, outros preceitos devem ser observados. Por exemplo, qualquer lei posterior pode limitar a autorização contida na anterior, ou porque assim disponha expressamente, ou porque regule a matéria que estava compreendida na autorização.

c) No regime da atual Constituição, quando a lei fôr de iniciativa do Parlamento, deve ela conter, com bastante amplitude, autorizações do gênero acima examinado. E' o que resulta do artigo 11: "A lei, quando de iniciativa do Parlamento, limitar-se-á a regular, de modo geral, dispondo apenas sôbre a substância e os princípios, a matéria que constitui o seu objeto. O Poder Executivo expedirá os regulamentos complementares".

Esta disposição, como observa Pontes de Miranda, presta-se a controvérsias, dada a imprecisão do seu texto. Nunca se pode saber exatamente que é a substância e que são os princípios da matéria objeto da lei 24. Sabe-se, de modo geral, que, em face dêsse dispositivo da Constituição, não deve o Parlamento, nas leis de sua iniciativa, descer a detalhes. Mas onde termina o substancial e começam as minúcias?

A melhor solução é interpretar-se o citado art. 11 como exigindo que as leis ali previstas contenham autorizações amplas para o poder executivo. A situação é a mesma da delegação contemplada no art. 12. Há, entre uma e outra disposição, apenas diferença de grau : a delegação do art. 11 é menos ampla do que a do artigo 12. Mas não há qualqueer sanção para a infração, por parte do Parlamento, da recomendação constante do art. 11. Pelo menos, sanção jurídica. Se o Parlamento, em leis de sua iniciativa, desce a detalhes que poderia abster-se de regular, não poderá o poder executivo, ao expedir os regulamentos complementares, contrariar

24 Comentários à Constituição Federal de 10 de novembro de 1937, vol. I, Rio, 1938, gágs. 320-1. "Em vez de um prêto, que é o da lei... e um branco que o Poder Pxecutivo, com os regulamentos, preenche, 0 art. 11 estabelece um problema sutil, tal a zona cinza em que importa a adoçäo dos dados conceptuais de "substância" e de "principtos". (pág. 321). 
as disposições legais. As normas regulamentares que o fizessem seriam inaplicáveis.

A sanção que a Constituição prevê para a infração do art. 11 é de natureza política. Em primeiro lugar, pode o Presidente da República substituir o projeto de iniciativa do Parlamento por um projeto governamental (art. $64, \S 2 .^{\circ}$ ). Em segundo lugar, pode vetá-lo, total ou parcialmente (art. 66). Se o Presidente não tiver substituído o projeto, ou o seu veto houver sido removido, pode ainda derrogar ou revogar a lei, durante o recesso do Parlamento, se a matéria fôr das compreendidas na competência legislativa originária que lhe outorga $o$ art. 13. Se nenhum dêsses recursos fôr eficaz, é porque haverá uma crise entre o Presidente e o Parlamento (crise, aliás, muito difícil de ocorrer no sistema da Constituição), e então as soluções jurídicas serão inadequadas para resolvê-la.

Argüir de inconstitucional uma lei do Parlamento porque disponha sôbre detalhes, em desacôrdo com a recomendação do artigo 11, é que não nos parece viável, em face da generalidade e imprecisão com que está redigido êsse dispositivo. $O$ art. 11 contém uma pura recomendação e, como tal, o seu alcance é apenas político e não jurídico. Os regulamentos complementares, a que o texto se refere, estão sujeitos às mesmas regras dos regulamentos de execução e dos regulamentos delegados. A legalidade de tais regulamentos depende do exame das disposiçóes da lei regulamentada, em cujo âmbito se deve conter.

d) Resta ainda falar dos regulamentos chamados autônomos, ou seja, segundo a definição de GNEIST, reproduzida por RUI BARBOSA no trecho já transcrito, aquêle "em que o poder executivo obra sôbre si nos vários domínios da administração públiea, ainda não ocupados pela legisilação". E' principalmente em tais regulamentos que se manifesta aquêle espírito de autoridade a que se refere HAURIOU 25 .

A questão oferece algumas dificuldades no tocante ao uso do poder de polícia que confere ao executivo esfera maior de atuação discricionária para resguardar a segurança, a saúde e o bem-estar da coletividade. Não cabe, neste trabalho, exame mais amplo do problema 26. Entretanto, cumpre, a respeito dêsses regulamentos autônomos, enunciar algumas idéias gerais que os abrangem, e que já foram desenvolvidas.

25 Op. cit., págs. 35+71.

26 'L'expression police désiéne l'ensemble des services or qanisés ou des mesures prescrites en vue d'assurer le maintien de l'ordre et de la salubrité à l'intérieur du pays... Les pouvoirs de police des administrateurs sont limités par les lois qui les leur assignent. C'est une règle de notre droit public qu'aucun ordre ne puisse être donné, qu'aucune défense ne puisse être faite par l'administration qu'en eplication d'un texte législatif" (H. BERTHtLEMY, Traité élémentaire de droit administratif, 8.2 ed., Paris, 1916, págs. 227 e 228). 
Em primeiro lugar, se a matéria, por fôrça de preceito constitucional, deve ser regulada por lei, o regulamento autônomo não a pode suprir. Em segundo lugar, se já existe lei sôbre a matéria, tem o regulamento de conformar-se com as suas disposições.

A questão se complica quando nem a Constituição exige lei para determinada matéria, nem existe ainda lei que sôbre ela disponha. Em tais casos o regulamento é válido, se não contraria qualquer princípio constitucional, pois nem à lei se permite que infrinja a Constituição, a não ser na hipótese do parágrafo único do art. 96 , quando a inconstitucionalidade tiver sido removida por aprovação qualificada do Parlamento.

14. No tocante ao princípio geral da submissão do regulamento à lei, exceção feita dos regulamentos delegados, em que é decisivo o exáme đa cláusula legal de autorização, é oportuno recordar os critérios apontados por Pimenta BuENo. Segundo êsse tratadista clássico do nosso direito público, o poder executivo, no uso da sua atribuição regulamentar, comete "grave abuso em qualquer das hipóteses seguintes": $10^{\circ} \mathrm{em}$ criar direitos, ou obrigações novas, não estabelecidas pela lei ...; $20^{\circ} \mathrm{em}$ ampliar, restringir ou modificar direitos ou obrigações...; $3^{\circ}$ em ordenar, ou proibir o que ela não ordena, ou não proíbe...; $4^{\circ}$ em facultar, ou proibir, diversamente do que a lei estabelece...; $5 .^{\circ}$, finalmente, em extinguir ou anular direitos ou obrigações. ..."27.

Carlos Maximiliano, consubstanciando êsses mesmos princípios e observações de outros autores (EsMEIN, GoODNow, RACIOPI Brunialti, Duguit, Barbalho, Filinto Bastos, Ribas, RodriGUES DE SOUSA), apresenta o seguinte quadro de limitações do poder regulamentar :

"O seu dever" (do executivo) "é cumprir, e não fazer a lei. Dai se deduzem, quanto ao poder regulamentar, várias restrições:

a) Não cria direitos nem obrigações não estabelecidas implícita ou explicitamente em lei.

b) Não amplia, restringe ou modifica direitos, nem obrigações. Apenas desenvolve e completa em particularidade as regras estabelecidas pelo Congresso.

c) Fica inteiramente subordinado à lei. Não faculta, ordena ou proíbe senão o que ela, em têrmos amplos, facultou, ordenou ou proibiu. em geral.

d) Não extingue direitos nem anula obrigações dos cidadãos

27 Direito público brasileiro análise da Constituiçāo do Império, Rio, 1857 \$ 326, pág 237. 
e) Limita-se a desenvolver os princípios e a completar a sua dedução, a fim de facilitar o cumprimento das lei; não deve estabelecer princípios novos.

f) Não cria empregos, nem fixa, eleva ou diminui vencimentos, institui penas, emolumentos ou taxas, senão quando expressamente autorizado pelo congresso.

g) Não revoga, nem contraria a letra nem o espírito da lei.

h) Quando esta determina a forma que deve revestir um ato, o regulamento apenas indica a maneira de cumprir aquelas formalidades, não institui outras novas.

i) Suspende ou adia a execução da lei sòmente quando esta o autoriza explìcitamente.

Se o executivo transgredir qualquer das nove regras aqui anunciadas, o regulamento não terá fôrça obrigatória e será repelido pelos tribunais":8.

Estas regras são ainda aplicáveis. Apenas onde o excerto se refere a Congresso diga-se lei, pois não é mais o parlamento, conforme já se acentuou, o único órgão legislativo na Constituição de 1937.

15. Que o regulamento que contrarie disposições legais, ou que exorbite da autorização concedida em lei ao executivo possa deixar de ser aplicado pelos órgãos judiciários é princípio que não comporta a menor dúvida 29 . Mas pode a autoridade administrativa deixar de aplicar o regulamento por motivo de ilegalidade?

Esta questão é mais complexa. Desde que o regulamento é editado pelo Presidente da República, que é a "autoridade suprema do Estado" que "promove orienta a politiea legislativa de interêsse nacional e superintende a administração do país" (art. 73), parece, à primeira vista, que nenhuma outra autoridade administrativa pode negar-lhe cumprimento. Aos prejudicados cumpre recorrer à justiça para anular a decisão proferida de acôrdo com disposições regulamentares ilegais.

A Constituição de 1934 havia atribuido ao Senado Federal uma competência até então desconhecida no nosso direito administrativo : a de "examinar, em confronto com as respectivas leis, os regulamen-

28 Comentários à Constituição Brasileira, 3.2 ed., Pôrto Alegre, 1929, n. 342 , págs. 542-3.

29 Sôbre a matéria dêste artigo, vejam-se, além dos autores já citados nas outras

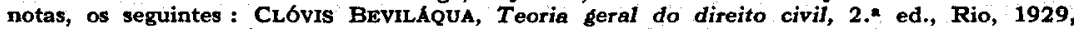
págs, 13-18; Temfstocles CavalcantI, Instituições de direito administrativo brasileiro, vol. I, "Rio, 1936, págs." 123 ss; ANTônIo JOAQUIM RIBAs,' Direito administrativo "brasileiro, Rio, 1866, págs. 199 ss; ARAÚJo CAstro, A nova Constituição brasileira, Rio, 1935, pág. 223 ; HERMEs LIMA, Introdução à ciência do direito, $2 .^{2}$ ed., 1934, cap. $X$, págs. 114 ss; H. Birrthelemy, Traité élémentaire de droit administratif, 8. ^ ed., Paris, 1916, págs. 13 ss; e os demais comentários existentes sôbre as nossas constituiçães. 
tos expedidos pelo Poder Executivo, e suspender a cxecução dos dispositivas ilegais" (art. 91, II). Essa providência visava obstar aos inconvenientes do regime do contrôle puramente judicial, pois, como é sabido, o judiciário só decide in casú, não podendo dispor genèricamente para outros casos além do que foi objeto da decisão. Idêntico propósito inspirou a disposição do art. 91, III, da mesma Constituição, que facultou ao Senado "suspender a execução, no todo ou em parte, de qualquer lei ou ato, deliberação ou regulamento", quando declarados inconstitucionais pelo judiciário. Sempre que o Senado usasse dessas atribuições, o regulamento tornarse-ia inaplicável, tanto para os juízes como para a administração em geral, não mais em virtude da sua ilegalidade ou inconstitucionalidade, mas por fôrça da suspensão determinada pelo Senado. A ilegalidade ou inconstitucionalidade seria a causa dessa suspensão, mas o regulamento deixaria, daí por diante, de ser aplicável por motivo da suspensão e não da causa que a teria determinado.

$\mathrm{Na}$ Constituição atual, não há nenhum órgão com essa atribuição, e não pode o judiciário, por imposição da natureza específica das suas decisões, declarar inaplicável um regulamento a outros casos semelhantes ao que porventura tiver julgado. Portanto, o regulamento, mesmo ilegal, obriga as autoridades administrativas inferiores e só pode ser suspenso ou revogado pela autoridade que o expediu.

Esta solução, entretanto, não parece aplicável ao caso em que - ato da autoridade administrativa possa ser qualificado crime. E' o que prescreve Ribas : "Na jurisprudência francesa, os regulamentos opostos às leis não são obrigatórios (DuFour, tít. 1. cap. $\left.1^{\circ}, n^{\circ} 51\right)$. O mesmo entre nós se deve entender, quando a antinomia entre a lei e o regulamento é manifesta, de sorte que a autoridade executora se ache colocada na alternativa de executar a lei e violar o regulamento, ou de executar o regulamento e violar a lei. Deve ela então demorar a execução para representar a êste respeito (Cód. Crim., art. 155, in fine), e em último caso deixar de executá-1o (Cód. Crim., arts. 142 e 143... )"30.

Essa restrição pode ser admitida em face do Código Penal vigente (Decreto-lei n. ${ }^{\circ} 2.848$, de 7 de dezembro de 1940), cujo artigo 19 dispõe: "Não há crime quando o agente pratica o fato... em estrito cumprimento de dever legal..." A execução de regulamento ilegal poderia não servir de escusa. Tanto mais que o Estatuto dos Funcionários Públicos Civis da União, no art. 224, II, declara dever do servidor "cumprir as ordens dos superiores, representando quando forem manifestamente ilegais". A hipótese, entretanto, é muito rara, porque é necessário: $10^{\circ}$ ) que o dispositivo re- 
gulamentar seja manifestamente ilegal, e $2 . \%$ ) que a prática do ato por êle determinado possa acarretar responsabilidade criminal.

Com esta única restrição, parece-nos que a autoridade administrativa inferior não pode negar aplicação, por motivo de ilegalidade, a regulamento emanado de autoridade superior.

\section{CONCLUSÃo}

16. As considerações dêste comentário referem-se às leis federais e aos regulamentos expedidos pelo Presidente da República. Não tratamos do assunto na órbita estadual, nem das instruçōes da competência dos ministros ou de autoridades inferiores. Esta matéria será possívelmente objeto de outros trabalhos. itens :

As presentes observações podem ser resumidas nos seguintes

I. Subsiste, entre-nós,-a-hierarquia entre lei e regulamento.

II. Tendo o Presidente da República, além das atribuições do poder executivo, competência legislativa originária, a invocação da competência constitucional em virtude da qual expede normas é que permite classificá-las como legais ou regulamentares.

III. Nos regulamentos autorizados em disposição especial de lei, é indispensável a menção dessa autorização para que o regulamento possa ser interpretado com menos rigor do que os expedidos em virtude da competência regulamentar genérica estabelecida no art. 74 , a, da Constituição 31 .

IV. As normas a que se referem os art. $61, b$ e $c$, e art. 62 da Constituição são regulamentares e não legais.

V. Os "regulamentos complementares" a que se refere o arfigo 11 da Constituição estão sujeitos às mesmas regras que governam os regulamentos de execução e os regulamentos delegados.

31 A Circular n.० 6/40, de 12 de agôsto de 1940, do Presidente da República, estabelece diversas regras para redação dos preâmbulos de decretos-leis e de decretos (Diário Oficial, de 14-8-40, pág. 14.448, e na Revista do Serviço Público, setembro de 1940).

Esta circular, entretanto, como vê do seu texto adiante, era incompleta, porque mão previa como casos especiais os dos arts. 12, 13 e 14 da Constituição :

"Normas, etc.

Preâmbulo dos decretos-leis e dos decretos executivos.

I - Dos decretos-leis :

O Presidente da República, usando da atribuição que the confere o artigo 180 da Constituiçã̉o,

Decreta :

II - Dos decretos executivos:

O Presidente da República, usando da atribuição que lhe confere o artiso 74 , letra a, da Constituição,

Decreta :

III - Dos decretos-leis e dos executivos, quando baixados na conformidade das competências definidas nas letras $b, c, e, f, b$ (última parte), $j, k, m$ e $n$, teräo, no preâmbulo, a indicação conveniente em lugar da letra a do artigo 74 ou do artigo 180 . 
VI. As autoridades administrativas, em regra, não podem negar aplicação, por motivo de ilegalidade, a regulamentos emanados de autoridade superior.

VII. O poder judiciário deve, em todos os casos submetidos ao seu exame, negar aplicação aos regulamentos ilegais ou inconstitucionais.

VIII. Os regulamentos declarados inconstitucionais pelo poder judiciário não podem ser "confirmados" pela via excepcional do art. 96, parágrafo único, da Constituição. 